\title{
The Effects of Cross-Border Bank Mergers on Bank Risk and Value
}

\author{
Yakov Amihud $^{\mathrm{a}}$, Gayle L. DeLong ${ }^{\mathrm{b}, *}$, Anthony Saunders ${ }^{\mathrm{c}}$
}

\begin{abstract}
This paper examines the effects of cross-border bank mergers on the risk and (abnormal) returns of acquiring banks. We find that overall, the acquirers' risk neither increases nor decreases. In particular, on average neither their total risk nor their systematic risk falls relative to banks in their home banking market. The abnormal returns to acquirers are negative and significant, but are somewhat higher when risk increases relative to banks in the acquirer's home country.
\end{abstract}

Revised, March 2002

${ }^{a}$ Ira L. Rennert Professor of Entrepreneurial Finance, Stern School of Business, New York University, 44 West $4^{\text {th }}$ Street, Suite 9-190, New York, NY 10012.

${ }^{\mathrm{b}}$ Assistant Professor of Finance, Zicklin School of Business, Baruch College, One Bernard Baruch Way, Box 10-225, New York, NY 10010.

${ }^{\mathrm{c}}$ John M. Schiff Professor of Finance, Stern School of Business, New York University, 44 West $4^{\text {th }}$ Street, Suite 9-190, New York, NY 10012.

We thank the referee, Eun Cheol, for comments and suggestions that helped to improve the paper.

*Corresponding author. Tel: 646-312-3493, Fax: 646-312-3451, E-mail: Gayle_DeLong@baruch.cuny.edu.

JEL classification: G14; G21; G34; F23.

Keywords: Banks; Mergers; Market reaction; International business. 


\section{Introduction}

A common argument in banking is that cross-border (geographic) mergers have the potential to reduce bank (and thus regulators') risk of insolvency (see Segal, 1974, Vander Vennet, 1996, and Berger, 2000). This conventional wisdom is based on the traditional notion that it is better for a bank not to put all its "eggs in one basket" and thus geographic diversification is a naturally risk reducing activity. However, offsetting these perceived benefits are at least two potential costs that may well enhance the risk of bank insolvency and ultimately the risk exposure of bank regulators. ${ }^{1}$

The first risk increasing effect comes from the incentives banks have to risk shift when the regulatory "safety net" and its associated implicit and explicit guarantees are underpriced. As discussed by John, John, and Senbet (1991) and John, Saunders, and Senbet (2000), banks have incentives to increase their risk exposure beyond the level that would be privately optimal in a world in which there were no safety net guarantees or the safety net - deposit insurance, capital requirements, and implicitly, bank closure - is

fairly priced. One way in which the safety net might be exploited is for a bank to acquire other (risky) banks by cross-border expansion. If the risky investment pays off, then the acquiring bank has the potential to keep any upside returns. If the acquisition of the foreign target fails and the domestic bank's (acquirer's) solvency is threatened, then the acquiring bank may be bailed out either by its own home or domestic regulator or perhaps by the host regulator (the regulator of the target bank). As a result, cross-border mergers may increase the insolvency risk exposure of either one or both the domestic (acquirer) and host (target) bank regulators. 
A second reason why cross-border acquisitions may increase an acquirer's risk concerns "who is watching the eggs in the basket" - see Winton (1999). Specifically, by extending its operations into new overseas markets, the (domestic) bank is confronted with potentially new and risk increasing monitoring problems related to the loan customer base, the operating cost structure, etc... of the target bank. If monitoring costs are high, these problems may also increase the insolvency risk of the domestic acquiring bank and implicitly the risk of domestic (and foreign) regulators.

The overall question as to whether cross-border mergers are net beneficial and to whom they are net beneficial (i.e., bank owners, bank regulators, etc.) remains an open question. For example, if cross-border mergers do not raise the risk of acquiring banks relative to other domestic (home country) banks, or indeed, reduces their risk, then domestic regulators may encourage domestic banks to expand abroad. By contrast, if cross-border mergers increase the relative domestic riskiness of the acquiring bank, then domestic regulators may wish to scrutinize such mergers more carefully and may even seek to restrict them in an effort to reduce safety net subsidies and to reduce risk-shifting behavior.

Similarly, with respect to the target (host) country, if the (foreign) acquiring bank's risk rises relative to the risk of host country banks, then foreign acquisitions may be viewed as undesirable in that they increase the insolvency risk of that host country's banking system.

To gain insight into these issues, we examine cross-border bank mergers from three perspectives. First, we analyze the change in total risk of an acquiring bank as a result of

\footnotetext{
${ }^{1}$ Cross-border bank mergers have been on the rise for over a decade. In 1985, Thomson Financial Securities Data reports twenty-eight cross-border bank mergers. By 2000, this number had climbed to 527.
} 
a cross-border banking merger. It is the acquiring bank's total risk relative to the risk of home banks that is of greatest concern to bank regulators (such as the Federal Deposit Insurance Corporation and Federal Reserve) in the acquirer's home country, because of the regulators' undiversified exposure to domestic bank risk. Second, we examine the changes in the systematic risk of acquiring banks relative to three bank indexes: the world bank index, the domestic bank index and the bank index of the host country (i.e. the country where the target is located). Third, we study the reaction of stock prices to news about the acquisition and examine the relationship between this stock price reaction and changes in risk brought about by cross-border bank mergers.

The main finding of our paper is that, on average, cross-border bank mergers do not change the risk of acquiring banks in any significant way. This finding has important regulatory policy implications in that the effect of an overseas acquisition is highly bank dependent or idiosyncratic. In particular, there are no general or average increases or decreases in either systematic or total risk. That is, on average the risk decreasing effects of cross-border bank mergers are offset by risk increasing effects, and the nature of the merging partners' operation changes in a way so as to leave the acquirer's risk unchanged. Thus, based on the historical sample analyzed in this paper, there is no overall need for regulators to be concerned with a rise in risk following cross-border mergers and there is no need to restrict them.

The paper proceeds as follows. Section 1 discusses the methodology used to measure geographic acquisition risk. Section 2 discusses the data used. Section 3 details the tests and their results, and Section 4 concludes. 


\section{Methodology}

We analyze the changes in the acquiring bank's risk after the cross-border acquisition is completed compared to its risk prior to the acquisition, relative to an index of all banks in three domiciles: the world, the home country and the host country (i.e., the country where the target is located). We also analyze the value (abnormal return) effects of these acquisitions. For the analysis of risk, we compare the acquirer's risk one year after the acquisition with its risk one year prior to the acquisition announcement. Specifically, we analyze data from 10 to 260 days after an acquisition is completed and compare the results with data from 10 to 260 days before an acquisition is announced. Since we analyze the acquirer's stock return, we convert the world and host country indexes to the currency of the acquirer's home country. For example, for a British acquirer of a German bank, we multiply the daily host country index (the German index) by the daily exchange rate for $\mathrm{f} / \mathrm{DM}$, and for the world index we multiply the world index, which is given in terms of U.S. dollars, by the daily exchange rate for $£ / \$$. Returns are calculated from these converted indexes. ${ }^{2}$

\subsection{Risk}

We measure the change in risk in two ways and compare its magnitude after the acquisition to that before the acquisition was announced.

\footnotetext{
${ }^{2}$ Exchange rates before 1986 come from the New York Fed. For exchange rate data starting in 1986, we use Datastream.
} 
1. Total relative risk. We calculate the ratio of the variance of the acquirer's daily stock returns to the variance of each of three bank index return series: world, home country and host country.

2. Systematic risk. We calculate the change in the beta coefficient of the acquiring bank's stock return relative to the returns on three bank indexes: the world bank index and the bank indexes of the home and host countries, controlling for the effects of the world bank index.

\subsection{Abnormal returns}

We measure abnormal returns to bank equity investors using the world, home, and host bank indexes as benchmarks. The event window that we consider is the 12-day period surrounding the announcement of the merger, from ten days before the merger announcement to one day after it was announced (days -10 to +1 ). The event window of 12 days captures possible leakages of information before the merger is announced. ${ }^{3} \mathrm{We}$ then analyze investor reaction to changes in total risk as well as to changes in systematic risk.

\section{Data}

We examine mergers where at least one partner is a commercial bank and the partners are headquartered in different countries. The acquirer owns at least $51 \%$ of the target after the merger, the merger must be completed by December 1999, and the acquirer must be traded on a major exchange. The Thomson Financial Securities Data Merger and

\footnotetext{
${ }^{3}$ For example, Cybo-Ottone and Murgia (2000) find significant leakage effects for cross-border mergers in the days just prior to announcements of European bank mergers.
} 
Acquisition Database lists 507 such mergers announced between 1985 and 1998. We use only those mergers where the acquirer's stock is publicly traded and daily stock return data are available in addition to the acquirer's country's bank and market indexes, and the target country's bank and market indexes. The data source for the individual banks' returns as well as the world, home, and host indexes is DataStream. Our final sample consists of 214 mergers.

\section{INSERT TABLE 1}

Table 1, Panel A shows the national identities of acquirers and targets (source: Thomson Financial Securities Data). While banks in countries such as Australia and the United Kingdom are active both in acquiring and being the targets of acquisitions, other countries such as Canada, France, Germany, Japan, and the Netherlands have at least $50 \%$ more cross-border acquisitions than targets. Countries that have targets but no acquirers are usually smaller or less developed. The U.S. has the largest number of target banks because it has by far the largest number of banks of any sample country. Until 1997, U.S. banks were restricted from pursuing full nationwide branch banking. ${ }^{4}$ This restriction, along with bank holding company legislation restraining domestic mergers, kept U.S. banks small relative to banks outside the United States. Since targets tend to be smaller banks, U.S. banks were attractive takeover targets. ${ }^{5}$

Table 1, Panel B shows the year each merger was announced from Thomson Financial Securities Data. The table reflects the steady growth in cross-border mergers that include a bank as at least one of the partners. We are able to find data for five mergers announced in 1985. By 1998, this number rises to 29.

\footnotetext{
${ }^{4}$ Until the final repeal of the McFadden Act in 1997 (phased in starting 1994), U.S. banks were not permitted to engage in interstate banking except under restricted circumstances.
} 
In nearly all acquisitions, the target was not a public company. Only 30 targets were publicly-traded, and for 12 of them we were able to find stock market information. For this subset, we calculated the weighted-average return on the portfolio of the acquirer and the target, the weights being the market capitalization of the target and acquirer ten days before the merger was announced. As with the world and host indexes, we convert the stock prices of the target into the acquirer's currency.

\section{Tests}

\subsection{Total risk}

A common measure of total risk is the variance of a firm's (bank's) stock return. We examine first the return variance of he acquiring bank relative to the variance of three bank return indexes. Denote $T R R_{j}=$ total relative risk of acquirer $j$,

$$
T R R_{j, k}=\frac{\operatorname{Var}\left(R_{j}\right)}{\operatorname{Var}\left(R B_{k}\right)}
$$

$R_{j}$ is the daily return on acquirer $j$ and $R B_{k}$ is the return on bank index $k$, where $k=$ world, home or host. We then calculate the change in the total relative risk, $\Delta T R R_{j, k}$,

$$
\Delta T R R_{j, k}=T R R_{j, k}(\text { after })-T R R_{j, k}(\text { before }),
$$

where "after" is days +10 to +260 after the acquisition is consummated, and "before" is days -260 to -10 before the announcement. In addition to examining the results for the entire sample, we divide the sample into subgroups according to the locations of the acquirers and targets. The subgroups are mergers involving:

1) U.S. acquirers,

2) U.K. acquirers,

\footnotetext{
${ }^{5}$ Buch and DeLong (2002) explore the determinants of cross-border bank mergers.
} 
3) European acquirers with European targets,

4) European acquirers with non-European targets, and

5) Acquirers from the rest of the world, mainly Australia, Canada, and Japan.

\section{INSERT TABLE 2}

Table 2, Panel A presents the results of the tests that compare the acquirer's (relative) risk before and after the acquisition. Neither the net risk increasing nor the net risk decreasing hypothesis is supported by the data. In particular, $\triangle T R R_{h o m e}$ and $\Delta T R R_{h o s t}$ are not significantly different from zero, using a Z-test. However, there is a weak indication of a decline in the acquirer's risk relative to its home bank index. That is, in most mergers, $56.07 \%$ of them, $\Delta T R R_{\text {home }}<0$ and all five median values of $\Delta T R R_{\text {home }}$ are negative.

It is instructive to compare the two groups of European bank acquisitions. The first group (60) has European targets, the second group (49) has non-European targets. Potentially, the two groups have two conflicting effects on the acquirer's risk. On the one hand, non-European targets may be more risky - partly because of exchange rate risk - than European targets and therefore contribute more to the acquirer's total risk. On the other hand, the non-European targets may provide greater diversification benefits because the business of a European acquirer may be less correlated with the business of a non-European target than with that of a European target. Overall, the evidence is that cross-border mergers between two European banks contribute less to the acquirer's risk than mergers between European and non-European banks. Notably, however, in both cases, the acquirer's risk does not rise relative to the home bank's risk (see $\Delta T R R_{\text {home }}$ column in Table 2, Panel A). Thus, the results show that while the acquirer's risk does 
not decline after cross-border bank merger, as would be expected from the simple diversification story, it does not rise either.

The results in Table 2 Panel A imply that in general, cross-border mergers do not lead acquirers to engage in post-merger risk shifting or risk increasing behavior. This result has important regulatory implications. Bank regulators that are concerned with the insolvency (total) risk of their domestic banking institutions need not be overly concerned that cross-border acquisition strategies pose a threat to domestic bank system stability. Neither is there an increase in total risk with respect to the bank index of the host country, where the target is located. Thus regulators in host countries may be less concerned about imposing barriers to foreign acquisitions.

In Table 2, Panel B, we examine whether the risk of the two merged banks put together changed after the merger. To that end, we calculate the return on a value-weighted portfolio of pairs of acquirer and target firms using their market values ten days before the announcement (see Eun et al., 1996). If the operational characteristics of the banks have not changed, there should be no change in the risk of this portfolio return relative to the benchmark indexes. The results in Table 2, Panel B show, however, that relative to the risk of a portfolio of the acquirer and target before the merger, the risk of the acquiring bank after the merger increases relative to all three benchmarks. Interestingly, before the merger, the correlation between the returns of the two banks, acquirer and target, was extremely small (0.0227 on average). This low correlation suggests a significant degree of potential diversification benefits impacting the total risk of a portfolio of the acquirer and target at the time of acquisition. After the acquisition, the operations of the acquirer and target became more integrated, which in turn is likely to have increased the correlation between their returns and thus increased their risk, compared to total risk prior to acquisition. 


\subsection{Systematic risk}

After a domestic bank acquires a foreign bank, there is a rise in the share of its income that is derived from foreign markets and a decline in the share of its income that is derived from the domestic market. It is thus expected that after the merger, the acquirer's return will show a weaker covariance with the home market banking index and a stronger covariance with foreign market banking indexes -- the world as a whole and in particular the country where the target bank is located. Agmon and Lessard (1977) showed, for U.S. multinational corporations, that the beta of their return with respect to the home market is lower and the beta on the world index is higher when the proportion of sales outside the U.S. is higher. We examine this issue here. We expect that a crossborder merger would reduce the acquirer's beta with respect to the home bank portfolio and raise its beta with respect to the world and host bank portfolios. While regulators are principally concerned about the total risk of a bank from engaging in cross-border mergers, they might want to observe whether the cross-border merger affects the extent to which the acquirer's return moves with the rest of the banks under its regulatory supervision. If, for example, the acquiring bank's beta with respect to the home market rises, it means that the cross-border merger augments the risk of banks in the home country rather than reduces it.

Specifically, we measure the acquiring bank's systematic risk - its $\beta$ coefficient relative to three bank indexes: world, home and host. To do this, we use the world bank index return, $R B_{\text {world }}$, and then include the home and host bank return indexes after having removed the effect of the world market index. This is obtained by regressing the home and host bank return indexes on the world market return index and then using the 
respective residuals, denoted $R B^{*}{ }_{h o m e}$ and $R B^{*}{ }_{h o s t}$. The estimated model for the return of stock $j$ on day $t, R_{j, t}$, is

$$
\begin{aligned}
R_{j, t}=\alpha_{j} & +\beta_{\text {world }, j} R B_{\text {world }, t}+\gamma_{\text {world }, j} R B_{\text {world }, t} D_{t}+\beta_{\text {home }, j} R B^{*}{ }_{\text {home }, t}+\gamma_{\text {home }, j} R B^{*}{ }_{\text {home }, t} D_{t} \\
& +\beta_{\text {host }, j} R B^{*}{ }_{\text {host }, t .}+\gamma_{\text {host }, j} R B^{*}{ }_{\text {host }, t} D_{t .}+u_{j, t} .
\end{aligned}
$$

$D_{t}$ is a dummy variable, $D_{t}=0$ for days -260 to day -10 before the merger announcement, and $D_{t}=1$ for days +10 to +260 after the consummation of the merger. We can directly obtain the change in beta, $\Delta \beta_{k, j}$, defined as follows:

$$
\Delta \beta_{k, j}=\beta_{k, j}(\text { after })-\beta_{k, j} \text { (before) }=\gamma_{k, j}
$$

where $k=$ world, home or host.

Our hypotheses are as follows:

(H1): $\Delta \beta_{\text {home }}$ should decline after cross-border mergers, since part of the acquirer's return is generated by banking activity abroad which is not perfectly correlated with banking activity in the home market.

(H2): $\Delta \beta_{\text {world }}$ and especially $\Delta \beta_{\text {host }}$ should rise since the acquirer's return in part reflects the return on banks (and their activities) in the countries where the target bank is doing business.

\section{INSERT TABLE 3}

Surprisingly, neither hypothesis is supported by the data. The results, presented in Table 3, Panel A, show that $\Delta \beta_{k, j}$ is not significantly different from zero for all three indexes. Again, this result should assuage both domestic and host country regulator concerns regarding the effects of cross-border bank acquisitions on the solvency of their banking systems. 
Table 3, Panel B analyzes the change in betas for the small subset of merger partners where we can find daily stock market return information for the target. Here, we compare the weighted-average betas of the merged partners before the merger is announced with the beta of the merged entity, where the weighting uses the acquirer's and target's market capitalization ten days before the merger is announced. We do find a significant increase in the beta for the world bank index of the acquirer (as expected) but no significant change in either home or host country betas.

\section{INSERT TABLE 4}

As a further check on the results in Table 3, Panel A, we examine the changes in the betas in a $2 \times 2$ matrix, where $\Delta \beta_{\text {home }}$ is tabulated against $\Delta \beta_{\text {host }}$ (Table 4 , Panel A) and $\Delta \beta_{\text {world }}$ (Table 4, Panel B). In Table 4, Panel A we expect the observations to more likely fall into the quadrants (cells) where $\Delta \beta_{\text {home }}<0$ and $\beta_{\text {host }}>0$. However, we find that only $28 \%$ of our sample adheres to this expectation. Indeed, the outcomes in the four cells are largely random (with randomness not being rejected by a $\chi^{2}$ test). In Table 4 , Panel B, we expect most cases to fall into the quadrant where $\Delta \beta_{\text {world }}>0$ and $\Delta \beta_{\text {home }}<0$. However, only $23.8 \%$ of the cases fall into this quadrant, with the rest being distributed randomly among the remaining three quadrants (randomness is not rejected by a $\chi^{2}$ test).

These results further confirm that cross-border bank related mergers do not significantly shift the acquirer's (systematic) risk away from the home market, as might be expected a priori.

So far, our analysis has been carried out using bank return indexes as the benchmark return indexes against which to measure relative risk changes, since we wish to compare the risk effects of banks that engage in cross-border merger activity versus those that do 
not. The effect of cross-border bank mergers on bank systematic risk could alternatively be examined using market indexes instead of bank indexes. However, doing this poses a problem since there are potentially factors that affect bank industry performance that are not captured by the market indexes. Specifically, our estimation of beta changes covers a relatively long period of time, 250 days before and after the bank merger. If, during that period, the performance of banking as an industry changes relative to the market as a whole - for example, due to a regulatory change that impacts all banks in a given country - then the betas of the merging banks would change although this change has nothing to do with the merger being analyzed. Thus, using the market index as a benchmark for our analysis would likely confound two effects: (1) the change in the acquirer's risk after the merger relative to the risk of all other banks, and (2) the change in the risk of the banking industry relative to the market as a whole.

To test for this possible confounding, we estimate two alternative equations (models):

$$
\begin{aligned}
& R_{j, t}=\alpha_{j}+\beta_{\text {world }, j} R M_{\text {world }, t}+\gamma_{\text {world }, j} R M_{\text {world }, t} D_{t}+\beta_{\text {home }, j} R M_{\text {home }, t} \\
& +\gamma_{\text {home }, j} R M_{\text {home }, t} D_{t}+\beta_{\text {host }, j} R M_{\text {host }, t .}+\gamma_{\text {host }, j} R M_{\text {host }, t} D_{t .}+u_{j, t} . \\
& R B_{j, t}=\alpha_{j}+\beta_{\text {world }, j} R M_{\text {world }, t}+\gamma_{\text {world }, j} R M_{\text {world }, t} D_{t}+\beta_{\text {home }, j} R M_{\text {home }, t} \\
& +\gamma_{\text {home }, j} R M^{*}{ }_{\text {home }, t} D_{t}+\beta_{\text {host }, j} R M^{*}{ }_{\text {host }, t .}+\gamma_{\text {host }, j} R M^{*}{ }_{\text {host }, t} D_{t .}+u_{j, t} .
\end{aligned}
$$

Model (5) is identical to our original model (3), except that it replaces the bank index $R B_{k}$ by the market index $R M_{k}$. In model (6), the dependent variable $R B_{j, t}$ is the bank index in the home country of acquirer $j$.

\section{INSERT TABLE 5}

The estimation results of these two models are presented in Table 5. For reasons of parsimony, we present only the results for the entire sample. The results for the first 
equation show increases in the market beta coefficients of acquirers after cross-border mergers against all three market indexes (only the increase in the world beta and home beta are significant). The estimation results of the second equation show that banks' systematic risk has risen over time relative to the market. That is, the beta coefficients of banks - irrespective of their involvement in cross-border mergers - increased during the period under study. The reasons for this increase in bank systematic risk is an interesting question in itself and is not analyzed here. However, these results support our use of bank industry indexes rather than market indexes as benchmarks in our study of cross-border bank acquisitions.

\subsection{Abnormal return effects}

This sub-section examines two questions:

1. Do cross-border bank mergers benefit the acquirer's stockholders relative to those of other banks not involved in cross-border mergers?

2. Is the return on the acquirer's stock related to changes in its risk?

To answer these questions, we proceed as follows. We first estimate cumulative abnormal returns (CARs) for the acquirer, using the following model

$$
R_{j, t}=\alpha_{j}+\beta_{\text {world }, j} R B_{\text {world }, t}+\beta_{\text {home }, j} R B_{\text {home }, t}+\beta_{\text {host }, j} R B_{\text {host }, t .}+\in_{j t}
$$

The model is estimated over days -260 to -10 before the announcement day. Then, we calculate the abnormal return for stock $j$ on day $t, A R_{j, t}$, as

$$
A R_{j, t}=R_{j, t}-\left(\alpha_{j}+\beta_{\text {world }, j} R B_{\text {world }, t}+\beta_{\text {home }, j} R B_{\text {home }, t}^{*}+\beta_{\text {host }, j} R B^{*}{ }_{\text {host }, t .}\right)
$$

where the parameters in the parentheses in equation (8) are estimated from model (7).

Finally, the cumulative twelve-day abnormal return, $C A R_{j}$, is calculated starting 10 days 
before the announcement, (day 0), to account for possible leakages of information, to one day after the announcement:

$$
C A R_{j}=\sum_{t=-10}^{+1} A R_{j, t}
$$

In general, we expect that banks only engage in acquisitions that are ex-ante value increasing. Moreover, in the case of banks, investors will rationally assign value to any mis- (under-) priced safety net guarantees (see Kane, 2000). These guarantees will potentially make bank acquisitions even more valuable to stockholders.

\section{INSERT TABLE 6}

Table 6.1, Panel A presents the results. The average $C A R$ is negative, approximately $-1 \%$, and is statistically significant. This result is consistent with acquirers overpaying for targets even in the presence of safety net subsidies. In nearly $63 \%$ of all cross-border mergers the acquirer had negative CARs (significantly different from a chance result of $50 \%$ ). Moreover, the average $C A R$ is negative for all five geographic groups. This means that cross-border acquisitions on their announcement were not perceived as beneficial to the acquiring bank stockholders relative to benchmark banks. Our results of negative acquirer's return resulting from cross-border acquisitions contrast with those of Doukas and Travlos (1988) for multinational firms. They found that for U.S. multinational acquirers who were not operating in the target's country, the acquisition announcement was associated with a significant positive excess returns, whereas for MNCs that were already operating in the target's country, the acquisition generated a small negative and insignificant excess returns. Eun et al. (1996) analyzed acquisitions of U.S. targets by foreign acquirers. On average, acquirers experienced negative abnormal returns, although the negative abnormal returns were insignificant. 
Our results are consistent with the results of a number of studies on domestic bank acquisitions. ${ }^{6}$ Hawawini and Swary (1990) found, for 126 bank acquisitions between 1968 and 1987, that the bidders' abnormal returns were negative and significant. Houston and Ryngaert (1994) also found negative abnormal returns for 153 bidding U.S. banks between 1985 and 1991. Cybo-Ottone and Murgia (2000) found that for 54 European bank mergers between 1988 and 1997, the acquirers' abnormal returns were insignificantly different from zero.

Examining the effects of cross-border acquisitions on the acquirer alone may overlook synergistic gains from cross-border mergers (see Eun et al., 1996). These synergistic gains are likely to be divided between the acquirer and its target. Following Eun et al. (1996), we examine where possible (given the data constraints), the total value creation in cross-border mergers to both acquirer and target. To do this, we examine the CARs on the weighted pairs of acquirers and targets for the 12 cases where these stock return data are available on both banks. The weights are the relative equity market values of the acquirer and target 10 days before the acquisition announcement.

As can be seen from Table 6.1, Panel B, the average $C A R$ on the portfolio of the acquirer and target is negative, $1.27 \%$, with $75 \%$ of the sub-sample having negative abnormal returns. While the statistical significance is low, because of the very small sample size, this evidence is consistent with the results of DeLong (2001) who found negative abnormal returns on average for U.S. domestic bank mergers that are geographically diversifying. However, the results are different from the results of Eun et al. (1996) on foreign acquisitions of U.S. target companies. The difference may reflect the difference in industry - we examine only bank acquisitions - and target country.

\footnotetext{
${ }^{6}$ For a comprehensive revise, see Piloff and Santomero (1998).
} 
Overall, our results suggest that the market value effect of cross-border mergers for bank stockholders is negative, notwithstanding possibly synergistic gains and the underpricing of bank safety nets.

We examine next whether the change in the acquirer value is related to changes in its risk. There are two opposing hypotheses.

(Ha) An increase in risk, particularly beta risk, raises the company's expected rate of return and thereby reduces its value if its cash flows remain unchanged. Thus, $C A R s$ should decline when beta risk increases.

$(\mathrm{Hb})$ In a highly levered company such as bank, an increase in risk induces a transfer of wealth from debt holders (and regulators/taxpayers) to stockholders. In the presence of wealth transfers, CARs should increase as risk increases.

We test these hypotheses in two ways. First, we estimate the effect on CARs of changes in beta coefficients:

$$
C A R_{j}=\gamma_{0}+\gamma_{1} \Delta \beta_{\text {world }, j}+\gamma_{2} \Delta \beta_{\text {home }, j}+\gamma_{3} \Delta \beta_{\text {host }, j}
$$

Hypothesis (Ha) implies $\gamma_{k}<0$ for $k=1,2$ and 3, while hypothesis $(\mathrm{Hb})$ implies $\gamma_{k}>0$. In estimating the model, we eliminated from each variable $\Delta \beta$ extreme outliers, i.e., the upper and lower $1 \%$ of the distribution of the respective variable leaving 203 merger cases in the sample to be estimated.

The results are presented in Table 6.2. The evidence appears to support neither hypothesis $(\mathrm{Ha})$ nor $(\mathrm{Hb})$. That is, acquirer's CARs appear to be unrelated to changes in beta risk.

As was discussed earlier, because of the relatively undiversified or industry specific exposure, domestic regulators are concerned with the total risk of the bank. Thus, from 
their viewpoint the proper benchmark is the home bank index. Consequently, we also estimate the model:

$$
C A R_{j}=\gamma_{0}+\gamma_{1} \Delta T R R_{j, h o m e}
$$

$\Delta T R R_{j, h o m e}$ is the change in total relative risk, as defined in (1), using the home banking index as benchmark. Again, we drop the extreme $1 \%$ of observations in each tail of the distribution of $\Delta T R R_{j, h o m e}$ from the sample. The results, presented in Table 6.3, give weak support to hypothesis $(\mathrm{Hb})$. The change in the acquirer's value as a result of cross-border acquisition is higher when the acquirer's risk rises relative to other home banks. We reestimated this model as follows:

$$
\begin{array}{ll}
\text { CAR }_{j}= & -0.015 \\
(t \text { stat. }) & (3.69)
\end{array}
$$

where $D U M P O S_{j}=1$ if $\triangle T R R_{j, h o m e}>0$ and zero otherwise. The results show that in cross-border mergers where there was a decline in total risk relative to the acquirer's home bank index, there was a significant decline in value of $1.5 \%$ (the value of the intercept coefficient). However, in mergers where the total risk increased, there was practically no decline in value -- the positive slope coefficient almost offsets the negative intercept. (In this regression, the slope coefficient was positive for all five geographical subgroups.) That is, investors were better off ex ante when the acquirer's risk increased after the merger. If acquirers overpaid for targets, a decrease in risk would exacerbate any loss of value by inducing a transfer of wealth from stockholders to creditors, depositors and regulators. However, an increase in risk offsets any overpayment by transferring wealth from regulators and creditors to stockholders. Apparently investors believe that regulators, directly or indirectly, will support (with guarantees and other 
mechanisms) the acquisition activities of large banks, even if they are ex-ante risk increasing.

\section{Summary and conclusions}

The growth of cross-border banking, largely driven by mergers and acquisitions, has raised concerns among regulators that the insolvency risk of banking systems will rise. Specifically, home country regulators are concerned that an acquirer's risk will rise relative to its domestic competitors, while host country regulators are concerned that the foreign acquirer may be more risky than the target it acquires. These concerns are heightened by the incentives banks have to increase risk in the presence of under-priced safety net guarantees and the difficulties that acquirers often have in monitoring and controlling the activities of their foreign acquisitions. Indeed, such effects may well offset any potential diversification gains that arise from geographic diversification.

Our main findings are interesting in that they suggest that whether an acquirer's risk rises or falls, following a cross-border acquisition, is highly idiosyncratic. On average, there is no evidence that cross-border merging banks add to the risk exposure of either domestic or host country regulators, whether looking at the total risk of the acquirer or its systematic risk relative to various banking industry indexes (home, host, world). These results hold for cross-border mergers in general and for various sub-samples of interregional cross-border mergers.

The policy implications of these results are clear, in that they do not support a systematic policy being adopted by regulators to limit cross-border acquisitions. Rather, 
they suggest (at least as far as risk is concerned) that a case by case approach should be adopted by both home and host country regulators.

In addition to our main findings, we examined the announcement effects of cross-border mergers on acquirer's abnormal returns. The CARs of acquiring banks were significantly negative (approximately 1\%). This result is consistent with acquiring banks overpaying for targets even in the presence of potential safety-net subsidies. Regressions linking acquirer CARs to either the systematic risk of the acquirer were generally insignificant, while the results show a weak positive effect of increase in the total risk (relative to the home bank index) on CARs. Again suggesting that even if significant risk shifting opportunities exist, via cross-border mergers, stockholders do not expect acquiring banks to exploit them, or that such risk shifting opportunities are limited.

In sum, the growth of cross-border banking appears to pose limited systemic risk dangers to the stability and solvency of the international banking system. 


\section{References}

Agmon, T., Lessard, D., 1977. Investor recognition of corporate international diversification. Journal of Finance 32 (4), 1049-1055.

Berger, A., 2000. The big picture of bank diversification. Proceedings, Federal Reserve of Chicago, May, 162-174.

Buch, C., DeLong, G., 2002. Cross-border bank mergers: What lures the rare animal? Working paper, Baruch College, New York, NY.

Cybo-Ottone, A., Murgia, M., 2000. Mergers and shareholder wealth in European banking. Journal of Banking and Finance 24 (6), 831-859.

DeLong, G. L., 2001. Stockholder gains from focusing versus diversifying bank mergers. Journal of Financial Economics 59 (2), 221-252.

Doukas, J., Travlos, N.G., 1988. The effect of corporate multinationalism on shareholders' wealth: evidence from international acquisitions. Journal of Finance 43 (5), 1611-1175.

Eun, C.S., Kolodny R., Scheraga C., 1996. Cross-border acquisitions and the shareholder wealth: tests of the synergy and internalization hypothesis. Journal of Banking and Finance 20 (9), 1559-1582.

Hawawini, G., Swary, I., 1990. Mergers and Acquisitions in the U.S. Banking Industry. North Holland.

Houston, J.F., Ryngaert, M.D., 1994. The overall gains from large bank mergers. Journal of Banking and Finance 18 (6), 1155-1176. 
John, K., John T., Senbet, L., 1991. Risk shifting incentives of depository institutions: a new perspective on Federal Deposit Insurance reform. Journal of Banking and Finance 15 (4-5), 895-915.

John, K., Saunders, A., Senbet, L., 2000. A theory of bank compensation and management regulation. Review of Financial Studies 3 (1), 95-126.

Kane, E., 2000. Incentives for banking megamergers: what motives might regulators infer from event-study evidence? Journal of Money, Credit, and Banking 32 (3), 671-699.

Piloff, S.J., Santomero, A.M., 1998. The value effects of bank mergers and acquisitions. In Amihud, Y. and Miller, G. (eds.) Bank Mergers and Acquisitions. Kluwer Academic Publishing.

Segal, Z., 1974. Market and Industry Factors Affecting Commercial Bank Stocks: An Analysis of the Price Behavior of Bank Stock Prices. Unpublished doctoral dissertation, New York University, New York.

Vander Vennet, R., 1996. The effect of mergers and acquisitions on the efficiency and profitability of EC credit institutions. Journal of Banking and Finance 20 (9), 1531-1558.

Winton, A., 1999. Don't put all your eggs in one basket? Diversification and specialization in lending. Working paper, University of Minnesota. 
Table 1

Cross-border bank mergers and acquisitions, 1985 - 1998

Panel A: National identities

\begin{tabular}{|c|c|c|}
\hline Country & Acquirers & Targets \\
\hline Argentina & 0 & 2 \\
\hline Austria & 0 & 4 \\
\hline Australia & 17 & 13 \\
\hline Belgium & 6 & 2 \\
\hline Brazil & 0 & 6 \\
\hline Canada & 13 & 3 \\
\hline Denmark & 3 & 1 \\
\hline Finland & 0 & 1 \\
\hline France & 28 & 12 \\
\hline Germany & 26 & 7 \\
\hline Hong Kong & 5 & 5 \\
\hline Ireland & 3 & 1 \\
\hline Italy & 4 & 8 \\
\hline Japan & 14 & 1 \\
\hline Luxembourg & 0 & 3 \\
\hline Malaysia & 2 & 0 \\
\hline Mexico & 0 & 3 \\
\hline Netherlands & 18 & 6 \\
\hline New Zealand & 0 & 7 \\
\hline Norway & 0 & 1 \\
\hline Philippines & 0 & 2 \\
\hline Poland & 0 & 4 \\
\hline Portugal & 0 & 3 \\
\hline Singapore & 4 & 3 \\
\hline South Africa & 1 & 3 \\
\hline South Korea & 2 & 0 \\
\hline Spain & 8 & 8 \\
\hline Sweden & 3 & 3 \\
\hline Switzerland & 10 & 5 \\
\hline Thailand & 0 & 1 \\
\hline United & 28 & 32 \\
\hline \multicolumn{3}{|l|}{ Kingdom } \\
\hline United States & 19 & 63 \\
\hline Venezuela & 0 & 1 \\
\hline Total & 214 & 214 \\
\hline
\end{tabular}


Panel B: Number of mergers announced per year

$\begin{array}{cc}\text { Year } & \begin{array}{c}\text { Number of } \\ \text { mergers }\end{array} \\ 1985 & 5 \\ 1986 & 8 \\ 1987 & 8 \\ 1988 & 12 \\ 1989 & 17 \\ 1990 & 16 \\ 1991 & 13 \\ 1992 & 15 \\ 1993 & 11 \\ 1994 & 14 \\ 1995 & 16 \\ 1996 & 24 \\ 1997 & 26 \\ 1998 & 29 \\ & \\ \text { Total } & \mathbf{2 1 4}\end{array}$


Table 2

Changes in total risk

Table 2, Panel A reports the change in the variance of the acquiring bank's variance of daily stock return relative to the variance of three bank return indexes. $T R R_{k, j}=$ total relative risk of acquirer $j, \operatorname{TR} R_{k, j}=\frac{\operatorname{Var}\left(R_{j}\right)}{\operatorname{Var}\left(R B_{k}\right)} \cdot R_{j}$ is the daily return on acquirer $j$ and $R B_{k}$ is the return on bank index $k$, where $k=$ world, home and host (the last two are the acquirer's home country and the target's country). The change in the total relative risk is $\Delta T R R_{k, j}, \Delta T R R_{k, j}=T R R_{k, j}$ (after) $-T R R_{k, j}$ (before), where "before" is days -260 to -10 before the announcement, and "after" is days +10 to +260 after the consummation of the merger.

The table reports the mean and median of $\Delta T R R_{k, j}$ and the proportion of cases where $\Delta T R R_{k, j}>0$. The number in parentheses are $t$-statistics of testing the hypothesis that $\Delta T R R_{k, j}=0$. The Z-statistics result from testing the hypothesis that the proportion of $\Delta T R R_{k, j}>$ 0 is 0.5 .

Table 2, Panel B reports the results tests for the 12 cases with public targets. The pre-merger returns are the weighted average of the partners, based on the market capitalization of the partners ten days before the merger is announced.

The study consists of 214 mergers announced between 1985 and 1998 where at least one partner is a commercial bank and partners are headquartered in different countries. All mergers were completed as of December 1999. 
Table 2 (continued)

\begin{tabular}{|c|c|c|c|c|c|c|c|c|c|}
\hline \multirow[b]{2}{*}{$\begin{array}{l}\text { Panel A: Acquirer's stock } \\
\text { Acquirer's country } \\
\text { (cases) }\end{array}$} & \multicolumn{3}{|c|}{$\Delta T R R_{\text {world }}$} & \multicolumn{3}{|c|}{$\Delta T R R_{\text {home }}$} & \multicolumn{3}{|c|}{$\Delta T R R_{\text {host }}$} \\
\hline & $\begin{array}{c}\text { Mean } \\
\text { (t-statistic) }\end{array}$ & Median & $\begin{array}{l}\% \text { positive } \\
\text { (Z-statistic) }\end{array}$ & $\begin{array}{c}\text { Mean } \\
\text { (t-statistic) }\end{array}$ & Median & $\begin{array}{l}\% \text { positive } \\
\text { (Z-statistic) }\end{array}$ & $\begin{array}{c}\text { Mean } \\
\text { (t-statistic) }\end{array}$ & Median & $\begin{array}{l}\% \text { positive } \\
\text { (Z-statistic) }\end{array}$ \\
\hline Entire sample (214) & $\begin{array}{c}-0.0701 \\
(-0.20)\end{array}$ & 0.1757 & $\begin{array}{c}53.74 \% \\
(1.09)\end{array}$ & $\begin{array}{c}-0.0193 \\
(-0.18)\end{array}$ & -0.0580 & $\begin{array}{c}43.93 \%{ }^{c} \\
(-1.78)\end{array}$ & $\begin{array}{c}-0.0983 \\
(-0.59)\end{array}$ & 0.0820 & $\begin{array}{c}54.21 \% \\
(1.23)\end{array}$ \\
\hline U.S. (19) & $\begin{array}{c}0.5346 \\
(0.93)\end{array}$ & -0.2390 & $\begin{array}{c}47.37 \% \\
(-0.23)\end{array}$ & $\begin{array}{c}0.0566 \\
(0.09)\end{array}$ & -0.3836 & $\begin{array}{c}47.37 \% \\
(-0.23)\end{array}$ & $\begin{array}{c}0.3770 \\
(0.87)\end{array}$ & -0.0532 & $\begin{array}{c}47.37 \% \\
(-0.23)\end{array}$ \\
\hline UK (28) & $\begin{array}{c}0.2240 \\
(0.66)\end{array}$ & 0.1455 & $\begin{array}{c}57.14 \% \\
(0.76)\end{array}$ & $\begin{array}{l}-0.0150 \\
(-0.13)\end{array}$ & -0.0649 & $\begin{array}{c}32.14 \%{ }^{\mathrm{c}} \\
(-1.89)\end{array}$ & $\begin{array}{c}-0.2275 \\
(-1.28)\end{array}$ & -0.1349 & $\begin{array}{c}42.86 \% \\
(-0.16)\end{array}$ \\
\hline $\begin{array}{l}\text { European acquirers of } \\
\text { European targets }(60)\end{array}$ & $\begin{array}{c}-0.8856 \\
(-1.01)\end{array}$ & -0.1455 & $\begin{array}{c}48.33 \% \\
(-0.25)\end{array}$ & $\begin{array}{c}-0.0944 \\
(-0.33)\end{array}$ & -0.0286 & $\begin{array}{c}46.67 \% \\
(-0.52)\end{array}$ & $\begin{array}{c}-0.1689 \\
(-0.40)\end{array}$ & 0.0950 & $\begin{array}{c}51.67 \% \\
(0.26)\end{array}$ \\
\hline $\begin{array}{l}\text { European acquirers of } \\
\text { non-European targets } \\
\text { (49) }\end{array}$ & $\begin{array}{c}0.3688^{\mathrm{c}} \\
(1.68)\end{array}$ & 0.5544 & $\begin{array}{c}61.22 \% \\
(1.57)\end{array}$ & $\begin{array}{l}-0.0129 \\
(-0.12)\end{array}$ & -0.0074 & $\begin{array}{c}48.98 \% \\
(-0.14)\end{array}$ & $\begin{array}{c}0.4318^{\mathrm{b}} \\
(2.08)\end{array}$ & 0.2778 & $\begin{array}{c}71.43 \%^{\mathrm{a}} \\
(3.00)\end{array}$ \\
\hline Rest of the world (58) & $\begin{array}{c}0.0624 \\
(0.07)\end{array}$ & 0.3421 & $\begin{array}{c}53.45 \% \\
(0.53)\end{array}$ & $\begin{array}{c}0.0260 \\
(0.20)\end{array}$ & -0.0910 & $\begin{array}{c}41.38 \% \\
(-1.31)\end{array}$ & $\begin{array}{c}-0.5664 \\
(-1.62)\end{array}$ & -0.0366 & $\begin{array}{c}50.00 \% \\
(0.00)\end{array}$ \\
\hline Panel B: A portfolio of 1 & $\begin{array}{l}\text { acquirers an } \\
1.1259^{\mathrm{b}} \\
(2.42)\end{array}$ & $\begin{array}{c}\text { argets, va } \\
0.8054\end{array}$ & $\begin{array}{l}\text { weighted }(\mathrm{b} \\
66.67 \% \\
(1.15)\end{array}$ & $\begin{array}{l}\text { h publicly tr } \\
0.3629^{\mathrm{b}} \\
(2.28)\end{array}$ & 0.1302 & $\begin{array}{c}66.67 \% \\
(1.15)\end{array}$ & $\begin{array}{l}0.5202^{b} \\
(2.23)\end{array}$ & 0.2598 & $\begin{array}{c}75.00 \% \mathrm{~b} \\
(1.73)\end{array}$ \\
\hline
\end{tabular}

a, b, c = statistically significant at the $1 \%, 5 \%$, and $10 \%$ level, respectively. 
Table 3

Changes in systematic risk

Table 3, Panel A reports the change in beta coefficient of the acquirer's return after the cross-border merger compared to beforehand.

$R_{j, t}=\alpha_{j}+\beta_{\text {world }, j} R B_{\text {world }, t}+\gamma_{\text {world }, j} R B_{\text {world }, t} D_{t}+\beta_{\text {home }, j} R B_{\text {home }, t}+\gamma_{\text {home }, j} R B_{\text {home }, t} D_{t}+\beta_{\text {host }, j} R B_{\text {host }, t .}+\gamma_{\text {host }, j} R B_{\text {host }, t} D_{t .}+u_{j, t}$

$R_{j, t}$ is the return on acquirer $j$ on day $t, R B_{k, t}$ is the bank index on day $\mathrm{t}$, where $k=$ world, home or host. $R B^{*}{ }_{\text {home, }}$ and $R B^{*}{ }_{\text {host }}$ are the residuals from a regression of the respective bank index return on $R B_{\text {world }}$, and $D$ is a dummy variable that is zero for days -260 to day -10 before the merger announcement, and one for days +10 to +260 after the consummation of the merger. We can directly obtain the change in beta from this equation: $\Delta \beta_{k, j}=\gamma_{k, j}$.

Table 3, Panel B reports the 12 cases or subset of mergers with public targets. The pre-merger returns are the weighted average of the partners, based on the market capitalization of the partners ten days before the merger is announced. 
Table 3 (continued)

\begin{tabular}{|c|c|c|c|c|c|c|c|c|c|}
\hline \multirow[b]{2}{*}{$\begin{array}{l}\text { Panel A: Acquirer's stock } \\
\text { Acquirer's country (cases) }\end{array}$} & \multicolumn{3}{|c|}{$\Delta \beta_{\text {world }}$} & \multicolumn{3}{|c|}{$\Delta \beta_{\text {home }}$} & \multicolumn{3}{|c|}{$\Delta \beta_{\text {host }}$} \\
\hline & $\begin{array}{c}\text { Mean } \\
\text { (t-statistic) }\end{array}$ & Median & $\begin{array}{l}\% \text { positive } \\
\text { (Z-statistic) }\end{array}$ & $\begin{array}{c}\text { Mean } \\
\text { (t-statistic) }\end{array}$ & Median & $\begin{array}{l}\% \text { positive } \\
\text { (Z-statistic) }\end{array}$ & $\begin{array}{c}\text { Mean } \\
\text { (t-statistic) }\end{array}$ & Median & $\begin{array}{l}\% \text { positive } \\
\text { (Z-statistic) }\end{array}$ \\
\hline Entire sample (214) & $\begin{array}{c}0.0032 \\
(0.26)\end{array}$ & 0.0022 & $\begin{array}{l}51.40 \% \\
(0.41)\end{array}$ & $\begin{array}{c}0.0159 \\
(0.95)\end{array}$ & 0.0015 & $\begin{array}{l}51.40 \% \\
(0.41)\end{array}$ & $\begin{array}{l}-0.0017 \\
(-0.18)\end{array}$ & -0.0009 & $\begin{array}{c}49.53 \% \\
(-0.14)\end{array}$ \\
\hline U.S. (19) & $\begin{array}{l}-0.0033 \\
(-0.06)\end{array}$ & 0.0258 & $\begin{array}{l}63.16 \\
(1.15)\end{array}$ & $\begin{array}{c}0.0245 \\
(0.28)\end{array}$ & -0.0313 & $\begin{array}{c}47.37 \\
(-0.23)\end{array}$ & $\begin{array}{l}-0.0445 \\
(-1.29)\end{array}$ & -0.0287 & $\begin{array}{l}36.84 \\
(-1.15)\end{array}$ \\
\hline UK (28) & $\begin{array}{l}-0.0523 \\
(-1.39)\end{array}$ & -0.0482 & $\begin{array}{l}39.29 \\
(-1.13)\end{array}$ & $\begin{array}{l}-0.0306 \\
(-0.85)\end{array}$ & -0.0131 & $\begin{array}{c}46.43 \\
(-0.38)\end{array}$ & $\begin{array}{l}-0.0149 \\
(-0.63)\end{array}$ & -0.0088 & $\begin{array}{l}46.43 \\
(-0.38)\end{array}$ \\
\hline $\begin{array}{l}\text { European acquirers of } \\
\text { European targets }(60)\end{array}$ & $\begin{array}{c}0.0199 \\
(0.94)\end{array}$ & 0.0097 & $\begin{array}{l}55.00 \\
(0.77)\end{array}$ & $\begin{array}{c}0.0318 \\
(1.21)\end{array}$ & 0.0210 & $\begin{array}{l}60.00 \\
(1.55)\end{array}$ & $\begin{array}{c}0.0055 \\
(0.21)\end{array}$ & 0.0006 & $\begin{array}{l}51.67 \\
(0.26)\end{array}$ \\
\hline $\begin{array}{l}\text { European acquirers of } \\
\text { non-European targets (49) }\end{array}$ & $\begin{array}{c}-0.0178 \\
(-1.00)\end{array}$ & -0.0209 & $\begin{array}{l}40.82 \\
(-1.29)\end{array}$ & $\begin{array}{c}0.0102 \\
(0.31)\end{array}$ & 0.0129 & $\begin{array}{l}48.98 \\
(-0.14)\end{array}$ & $\begin{array}{c}-0.0078 \\
(-0.57)\end{array}$ & -0.0037 & $\begin{array}{c}46.94 \\
(-0.43)\end{array}$ \\
\hline Rest of the world (58) & $\begin{array}{l}0.0327 \\
(1.28)\end{array}$ & 0.0234 & $\begin{array}{l}58.62 \\
(1.31)\end{array}$ & $\begin{array}{c}0.0237 \\
(0.67)\end{array}$ & -0.0081 & $\begin{array}{c}48.28 \\
(-0.26)\end{array}$ & $\begin{array}{c}0.0163 \\
(0.92)\end{array}$ & 0.0146 & $\begin{array}{l}55.17 \\
(0.79)\end{array}$ \\
\hline anel B: A portfolio of 12 & $\begin{array}{c}\text { irers and t } \\
0.0431 \\
(1.37)\end{array}$ & $\begin{array}{c}\text { ts, value } \\
0.0568\end{array}$ & $\begin{array}{c}\text { ghted (both } \\
75.00^{\mathrm{b}} \\
(1.73)\end{array}$ & $\begin{array}{c}\text { blicly trade } \\
0.0697 \\
(1.58)\end{array}$ & 0.1309 & $\begin{array}{l}58.33 \\
(0.58)\end{array}$ & $\begin{array}{c}-0.0040 \\
(-0.10)\end{array}$ & 0.0009 & $\begin{array}{l}50.00 \\
(0.00)\end{array}$ \\
\hline
\end{tabular}

$\mathrm{a}, \mathrm{b}, \mathrm{c}=$ statistically significant at the $1 \%, 5 \%$, and $10 \%$ level, respectively. 
Table 4

Matrices of changes in betas on home and host bank return indexes and on home and world bank return indexes as a result of a crossborder bank merger

The table reports the change in systematic risk before and after a cross-border merger. Systematic risk is measured as the beta resulting from a regression of the acquiring bank's return on the world, home, and host bank return indexes. See Table 3 for details.

Panel A: Home and host bank indexes

\begin{tabular}{|c|c|c|c|c|}
\hline & & & & \\
\hline & & Decreases & Increases & \\
\hline & Decreases & $22.4 \%$ & $26.2 \%$ & $\begin{array}{l}\text { Total } \\
48.6 \%\end{array}$ \\
\hline & Increases & 28.0 & 23.4 & 51.4 \\
\hline Total & & 50.4 & 49.6 & 100 \\
\hline
\end{tabular}

Panel B: Home and world bank indexes

\begin{tabular}{|c|c|c|c|c|}
\hline & & $\beta_{h}$ & & \\
\hline & & Decreases & Increases & \\
\hline & Decreases & $24.8 \%$ & $23.8 \%$ & $48.6 \%$ \\
\hline & Increases & 23.8 & 27.6 & 51.4 \\
\hline & & 48.6 & 51.4 & 100 \\
\hline
\end{tabular}

$\mathrm{H}_{0}: 25 \%$ of observations in each cell

$\chi^{2}=0.80, \mathrm{df}=1, \mathrm{p}=0.3700$ 
Table 5

Changes in systematic risk using market indexes as benchmarks.

The table reports the change in the beta coefficient of the acquirer's return after cross-border merger compared to beforehand.

Model 1: $R_{j, t}=\alpha_{j}+d_{j}+\beta_{\text {world }, j} R M_{\text {world }, t}+\gamma_{\text {world }, j} R M_{\text {world }, t} D_{t}+\beta_{\text {home }, j} R M_{\text {home }, t}+\gamma_{\text {home }, j} R M_{\text {home }, t} D_{t}+\beta_{\text {host }, j} R M_{\text {host } t .}$

$$
+\gamma_{\text {host }, j} R M^{*}{ }_{\text {host }, t} D_{t .}+u_{j, t,}
$$

Model 2: $R B_{j, t}=\alpha_{j}+d_{j}+\beta_{\text {world }, j} R M_{\text {world }, t}+\gamma_{\text {world }, j} R M_{\text {world }, t} D_{t}+\beta_{\text {home }, j} R M^{*}$ home,$t+\gamma_{\text {home }, j} R M^{*}{ }_{\text {home }, t} D_{t}+\beta_{\text {host }, j} R M^{*}$ host,$t$.

$$
+\gamma_{\text {host }, j} R M^{*}{ }_{\text {host }, t} D_{t .}+u_{j, t}
$$

$R_{j, t}$ is the return on acquirer $j$ on day $t$, and $R B_{j, t}$ is the bank index of the home country of acquirer $j, R M_{k, t}$ is the market index where $k$ $=$ world, home or host. $R M^{*}{ }_{h o m e}$, and $R M^{*}$ host are the residuals from a regression of the respective market index return on $R M_{\text {world }}$, and $D$ is a dummy variable that is zero for days -260 to day -10 before the merger announcement and one for days +10 to +260 after the consummation of the merger. $\Delta \beta_{k}=\gamma_{k, j}$.

The study consists of 214 mergers announced between 1985 and 1998 where at least one partner is a commercial bank and

\begin{tabular}{|c|c|c|c|c|c|c|c|c|c|}
\hline \multirow[t]{2}{*}{ Model } & \multicolumn{3}{|c|}{$\Delta \beta_{\text {world }}$} & \multicolumn{3}{|c|}{$\Delta \beta_{\text {home }}$} & \multicolumn{3}{|c|}{$\Delta \beta_{\text {host }}$} \\
\hline & $\begin{array}{c}\text { Mean } \\
\text { (t-statistic) }\end{array}$ & Median & $\begin{array}{c}\% \text { positive } \\
\text { (Z-statistic) }\end{array}$ & $\begin{array}{c}\text { Mean } \\
\text { (t-statistic) }\end{array}$ & Median & $\begin{array}{l}\% \text { positive } \\
\text { (Z-statistic) }\end{array}$ & $\begin{array}{c}\text { Mean } \\
\text { (t-statistic) }\end{array}$ & Median & $\begin{array}{l}\% \text { positive } \\
\text { (Z-statistic) }\end{array}$ \\
\hline 1 & $\begin{array}{c}0.0493^{\mathrm{b}} \\
(2.67)\end{array}$ & 0.0343 & $\begin{array}{c}57.94 \% \text { b } \\
(2.32)\end{array}$ & $\begin{array}{c}0.0503^{\mathrm{b}} \\
(2.22)\end{array}$ & 0.0214 & $\begin{array}{c}52.34 \% \\
(0.68)\end{array}$ & $\begin{array}{c}0.0214 \\
(1.43)\end{array}$ & 0.0131 & $\begin{array}{c}51.87 \% \\
(0.55)\end{array}$ \\
\hline 2 & $\begin{array}{c}0.0510^{\mathrm{a}} \\
(3.88)\end{array}$ & 0.0711 & $\begin{array}{c}61.22 \%{ }^{\mathrm{a}} \\
(3.28)\end{array}$ & $\begin{array}{c}0.0257 \\
(1.51)\end{array}$ & 0.0306 & $\begin{array}{c}50.47 \% \\
(0.14)\end{array}$ & $\begin{array}{c}0.0149^{b} \\
(2.04)\end{array}$ & 0.0130 & $\begin{array}{l}(54.21 \\
(1.23)\end{array}$ \\
\hline
\end{tabular}
partners are headquartered in different countries. All mergers were completed as of December 1999. 
Table 6

Market reaction to changes in systematic risk

The table reports cumulative abnormal return on the acquiring stock around the time of the announcement, and the effect of changes in risk.

Table 6.1 measures the abnormal returns for stock $j$ on day $t, A R_{j, t}$ estimated using a three factor market model:

$$
A R_{j, t}=R_{j, t}-\left(\alpha+\beta_{\text {world }, j} R B_{\text {world }, t}+\beta_{\text {home }, j} R B^{*}{ }_{h o m e, t}+\beta_{h o s t, j} R B^{*}{ }_{h o s t, t . t}\right) .
$$

The model is estimated over days -260 to -10 before the announcement. The cumulative twelve-day abnormal return, $C A R_{j}$, is

$$
C A R_{j}=\sum_{t=-10}^{+1} A R_{j, t} .
$$

Table 6.2 measures the effects of changes in systematic risk on $C A R$, using the model:

$$
C A R_{j}=\gamma_{0}+\gamma_{1} \Delta \beta_{\text {world }, j}+\gamma_{2} \Delta \beta_{\text {home }, j}+\gamma_{3} \Delta \beta_{\text {host }, j} .
$$

In this regression, outliers that are at the top and bottom $1 \%$ of the distribution of each RHS variable are removed.

Table 6.3 measures the effect of changes in total relative risk on $C A R$, using the model:

$$
C A R_{j}=\gamma_{0}+\gamma_{1} \Delta T R R_{j, h o m e} .
$$

In this regression, outliers that are at the top and bottom $1 \%$ of the distribution of each RHS variable are removed. 
Table 6 (continued)

Table 6.1: Cumulative abnormal returns (CARs), descriptive statistics

Panel A: CARs around acquisition announcement (acquirers only).

\begin{tabular}{|c|c|c|c|c|c|}
\hline Acquirer's country (cases) & $\begin{array}{c}\text { Mean } \\
\text { (t-statistic) }\end{array}$ & Median & $\begin{array}{l}\% \text { positive } \\
\text { (Z-statistic) }\end{array}$ & Minimum & Maximum \\
\hline $\begin{array}{l}\text { Panel A: Acquirer's stock } \\
\text { Entire sample (214) }\end{array}$ & $\begin{array}{c}-0.0098^{\mathrm{a}} \\
(-3.08)\end{array}$ & -0.0091 & $\begin{array}{l}37.38 \%{ }^{\mathrm{a}} \\
(-3.69)\end{array}$ & -0.1498 & 0.2013 \\
\hline U.S. (19) & $\begin{array}{l}-0.0053 \\
(-0.52)\end{array}$ & 0.0008 & $\begin{array}{l}52.64 \\
(0.23)\end{array}$ & -0.0792 & 0.1089 \\
\hline UK (28) & $\begin{array}{c}-0.0238^{a} \\
(-2.93)\end{array}$ & -0.0285 & $\begin{array}{l}28.57^{b} \\
(-2.27)\end{array}$ & -0.1013 & 0.0896 \\
\hline $\begin{array}{l}\text { European acquirers of } \\
\text { European targets (60) }\end{array}$ & $\begin{array}{c}-0.0016 \\
(-0.27)\end{array}$ & -0.0033 & $\begin{array}{l}43.33 \\
(-1.03)\end{array}$ & -0.1015 & 0.2013 \\
\hline $\begin{array}{l}\text { European acquirers of } \\
\text { non-European targets (49) }\end{array}$ & $\begin{array}{c}-0.0129^{c} \\
(-1.79)\end{array}$ & -0.0133 & $\begin{array}{l}32.65^{b} \\
(-2.43)\end{array}$ & -0.1498 & 0.1360 \\
\hline Rest of the world (58) & $\begin{array}{l}-0.0103^{c} \\
(-1.73)\end{array}$ & -0.0123 & $\begin{array}{l}34.48^{\mathrm{b}} \\
(-2.36)\end{array}$ & -0.1373 & 0.1450 \\
\hline
\end{tabular}

Panel B: A portfolio of 12 acquirers and targets, market value weighted (both publicly traded)

$\begin{array}{lllll}-0.0127 & -0.0094 & 25.00^{\mathrm{b}} & -0.0837 & 0.0248 \\ (-1.68) & & (-1.73) & & \end{array}$

a, b, c = statistically significant at the $1 \%, 5 \%$, and $10 \%$ level, respectively. 


\section{Table 6 (continued)}

Table 6.2

Regression results of CAR on changes in betas

$\begin{array}{lccccc}\text { Acquirer's country (cases) } & \begin{array}{c}\text { Constant } \\ \text { (t-statistic) }\end{array} & \begin{array}{c}\Delta \beta_{\text {world }} \\ \text { (t-statistic) }\end{array} & \begin{array}{c}\Delta \beta_{\text {home }} \\ \text { (t-statistic) }\end{array} & \begin{array}{c}\Delta \beta_{\text {host }} \\ \text { (t-statistic) }\end{array} & \text { Adjusted-R }^{2} \\ \text { Panel A: Acquirer's stock } & -0.0108^{\mathrm{a}} & 0.0218 & 0.0109 & -0.0362 & 0.39 \% \\ \text { Entire sample (203) } & (-3.31) & (0.79) & (0.75) & (-1.17) & \\ & -0.0129 & 0.0153 & 0.0476^{\mathrm{c}} & 0.0076 & 4.82 \\ \text { U.S. (18) } & (-1.53) & (0.24) & (1.81) & (0.0810) & \\ & -0.0218^{\mathrm{b}} & 0.0573 & -0.0025 & -0.0627 & -0.02 \\ \text { U.K. (28) } & (-2.13) & (0.85) & (-0.08) & (-0.71) & \\ & -0.0005 & -0.0686 & -0.0242 & -0.0409 & -0.91 \\ \text { European acquirers of } & (-0.08) & (-0.69) & (-0.90) & (-0.89) & \\ \text { European targets (57) } & -0.0140^{\mathrm{c}} & 0.0660 & 0.0494 & -0.0853 & 3.69 \\ \text { European acquirers of } & (-1.95) & (0.70) & (1.47) & (-0.88) & \\ \text { non-European targets (48) } & -0.0095 & 0.0101 & -0.0268 & -0.0090 & -0.04 \\ \text { Rest of the world (53) } & (-1.32) & (0.30) & (-0.97) & (-0.11) & \\ & -0.0068 & -0.0151 & -0.0808 & -0.0747 & 24.338 \\ \text { Panel B: A portfolio of 12 acquirers and targets, value weighted (both publicly traded) } & \end{array}$

a, b, c $=$ statistically significant at the $1 \%, 5 \%$, and $10 \%$ level, respectively. 


\section{Table 6.3}

Regression results of CAR on changes in total relative to the acquirer's home bank index.

$\begin{array}{lccc}\text { Acquirer's country (cases) } & \text { Constant } & \begin{array}{c}\Delta T R R_{\text {home }} \\ \text { (t-statistic) }\end{array} & \text { Adjusted-R }{ }^{2} \\ \text { Panel A: Acquirer's stock } & -0.0095^{\mathrm{a}} & 0.0045^{\mathrm{c}} & 0.50 \% \\ \text { Entire sample (209) } & (-2.98) & (1.71) & \\ & -0.0023 & 0.0057^{\mathrm{c}} & -0.58 \\ \text { U.S. (17) } & (-0.21) & (2.05) & \\ & -0.0236^{\mathrm{a}} & 0.0155^{\mathrm{c}} & 0.01 \\ \text { U.K. (28) } & (-3.01) & (1.77) & \\ & -0.0005 & 0.0016 & -0.02 \\ \text { European acquirers of } & (-0.08) & (0.28) & \\ \text { European targets (57) } & -0.0127^{\mathrm{c}} & 0.0175^{\mathrm{c}} & 4.68 \\ & (-1.79) & (1.81) & \\ \text { European acquirers of } & -0.0103^{\mathrm{c}} & -0.0027 & -0.01 \\ \text { non-European targets (49) } & (-1.72) & (-0.63) & \\ \text { Rest of the world (58) } & & \end{array}$

Panel B: A portfolio of 12 acquirers and targets, value weighted (both publicly traded)

$\begin{array}{lll}-0.0108 & -0.0052 & -0.09 \\ (-1.72) & (-0.47) & \end{array}$

a, b, c $=$ statistically significant at the $1 \%, 5 \%$, and $10 \%$ level, respectively. 